\title{
Biorefining strategy for maximal monosaccharide recovery from three different feedstocks: Eucalyptus residues, wheat straw and olive tree pruning
}

\author{
Talita Silva-Fernandes a,b ${ }^{\mathrm{a}}$, Luís Chorão Duarte ${ }^{\mathrm{a}}$, Florbela Carvalheiro a , Susana Marques ${ }^{\text {a }}$, \\ Maria Conceição Loureiro-Dias ${ }^{\mathrm{b}}$, César Fonseca ${ }^{\mathrm{a}, *}$, Francisco Gírio ${ }^{\mathrm{a}}$ \\ a Laboratório Nacional de Energia e Geologia, I.P. (LNEG), Unidade de Bioenergia, Estrada do Paço do Lumiar 22, 1649-038 Lisboa, Portugal \\ ${ }^{\mathrm{b}}$ Instituto Superior de Agronomia (ISA), Universidade de Lisboa, Linking Landscape, Environment, Agriculture and Food (LEAF), Tapada da Ajuda, 1349-017 Lisboa, Portugal
}

\section{H I G H L I G H T S}

- ER, WS and OP are suitable feedstocks for Southern European biorefineries.

- The proposed biorefining strategy is efficient for monosaccharide recovery.

- Maximal monosaccharide recovery was obtained after autohydrolysis at $210^{\circ} \mathrm{C}$.

- Maximal cellulose enzymatic digestibility was obtained after autohydrolysis at $230^{\circ} \mathrm{C}$.

- The conditions for maximal sugar recovery yield were similar for all feedstocks.

\section{A R T I C L E I N F O}

\section{Article history:}

Received 30 October 2014

Received in revised form 28 January 2015

Accepted 30 January 2015

Available online 7 February 2015

\section{Keywords:}

Lignocellulosic materials

Sugar-based biorefinery

Autohydrolysis

Enzymatic hydrolysis

Chemical post-hydrolysis

\begin{abstract}
A B S T R A C T
This work proposes the biorefining of eucalyptus residues (ER), wheat straw (WS) and olive tree pruning (OP) combining hydrothermal pretreatment (autohydrolysis) with acid post-hydrolysis of the liquid fraction and enzymatic hydrolysis of the solid fraction towards maximal recovery of monosaccharides from those lignocellulose materials. Autohydrolysis of ER, WS and OP was performed under non-isothermal conditions $\left(195-230^{\circ} \mathrm{C}\right.$ ) and the non-cellulosic saccharides were recovered in the liquid fraction while cellulose and lignin remained in the solid fraction. The acid post-hydrolysis of the soluble oligosaccharides was studied by optimizing sulfuric acid concentration $(1-4 \% \mathrm{w} / \mathrm{w})$ and reaction time (10-60 $\mathrm{min})$, employing a factorial $\left(2^{2}\right)$ experimental design. The solids resulting from pretreatment were submitted to enzymatic hydrolysis by applying commercial cellulolytic enzymes Celluclast ${ }^{\circledR} 1.5 \mathrm{~L}$ and Novozyme ${ }^{\circledR} 188$ ( 0.225 and $0.025 \mathrm{~g} / \mathrm{g}$ solid, respectively). This strategy provides high total monosaccharide recovery or high glucose recovery from lignocellulosic materials, depending on the autohydrolysis conditions applied.
\end{abstract}

(c) 2015 Elsevier Ltd. All rights reserved.

\section{Introduction}

Lignocellulosic materials are the largest renewable and potentially sustainable source of biomass that can be used in a biorefinery framework for the production of fuels, chemicals and materials (FitzPatrick et al., 2010; Ghatak, 2011). Eucalyptus residues (ER),

\footnotetext{
Abbreviations: OS, oligosaccharides; GlcOS, gluco-oligosaccharides; XOS, xylooligosaccharides; AOS, arabino-oligosaccharides; GalOS, galacto-oligosaccharides; MOS, manno-oligosaccharides; HMF, 5-(hydroxymethyl)furfural; $X_{1}$, sulfuric acid concentration; $X_{2}$, isothermal reaction time.

* Corresponding author. Tel.: +351 210924717.

E-mail address: cesar.fonseca@lneg.pt (C. Fonseca).
}

wheat straw (WS) and olive tree pruning (OP) are lignocellulosic materials largely available in Southern Europe (Faraco and Hadar, 2011), and their abundance in the Iberian Peninsula (Spain and Portugal, area of approx. 582,000 $\mathrm{km}^{2}$ ) is estimated in $2.8 \times 10^{6}$, $1.0 \times 10^{7}$ and $4.0 \times 10^{6}$ ton per year of ER, WS and OP (European Union, 2013; FAOSTAT, 2014; Kim and Dale, 2004; RomeroGarcía et al., 2014). Therefore, ER, WS, and OP, have been considered for the biomass supply chain of biorefineries within this region. In fact, considering that a biorefinery could operate with $50 \%$ of the feedstocks available within $80 \mathrm{~km}$ radius, it would be possible to process, in average, approx. 1,000 ton/day, which could generate circa 50 million L of lignocellulosic ethanol per year. 